\title{
A Study of the Impact of Treatment Response to Direct Acting Antivirals on Serum Lipid Profile in Egyptian Patients with Chronic HCV Infection
}

\author{
MARIAM N. NAGUIB, M.Sc.*; ABDELRAHMAN A. KOBTAN, M.D.*; \\ AMAL H. ABD ELHAMEED, M.D.** and MAHMOUD A. KHEDR, M.D.* \\ The Departments of Tropical Medicine* and Clinical Pathology**, Faculty of Medicine, Tanta University
}

\begin{abstract}
Background: Hepatitis C virus infection is a major etiological factor for liver cirrhosis, steatosis, and hepatocellular carcinoma. HCV is known to be closely related and associated with host and lipid metabolism.

Aim of Study: This study aimed at studying the changes in serum lipid profile with INF-free treatment regimens in chronic HCV infection.

Patients and Methods: This prospective observational cohort study was carried out on 301 chronic HCV-infected patients, who had fulfilled the inclusion \& exclusion criteria and treated according to the National Committee of Control of Viral Hepatitis (NCCVH) Treatment Protocol, updated in December 2016, and completed their course of treatment and follow-up. They were divided into two groups. Group I included 264 patients, who achieved SVR and Group II included 37 patients who did not achieve SVR. Patients underwent additional investigations in the form of $12 \mathrm{~h}$ fasting serum lipids profile $(\mathrm{mg} / \mathrm{dl})$ including: Serum cholesterol, serum triglycerides, Low Density Lipoprotein (LDL), High Density Lipoprotein (HDL). These tests were done before starting treatment (baseline), at the end of treatment.
\end{abstract}

Results: There was a statistically significant difference between responder and non-responder groups as regard baseline cholesterol $(p=0.001)$, LDL $(p=0.001)$, HDL $(p=0.026)$ and triglycerides levels $(p=0.016)$. These lipid parameters increased significantly over the course of the therapy and continued to be increased after treatment discontinuation in responders; while they showed non-significant changes in non-responders.

Conclusions: Viral eradication was associated with increased serum cholesterol, TG \& LDL levels, which continued to be elevated after discontinuation of therapy.

Key Words: Serum lipid profile - Chronic HCV infection patients.

\section{Introduction}

HCV infection is one of the leading causes of liver cirrhosis, Hepatocellular Carcinoma (HCC), and

Correspondence to: Dr. Mariam N. Naguib, The Department of Tropical Medicine, Faculty of Medicine, Tanta University liver transplantation in Egypt. Hence, patients with $\mathrm{HCV}$ infection are in need for effective antiviral therapy to prevent the progression to these complications and reduce mortality [1]

Recently, a revolution has occurred with the availability of Direct-Acting Antivirals (DAAs) in the treatment of $\mathrm{HCV}$, with different modes of action leading to high chance of cure and a good tolerance [2].

$\mathrm{HCV}$ infection is known to modify the host lipid metabolism; the virus uses host lipids in every step of its replication cycle from attachment and entry into hepatocytes, to replication and assembly of new viral particles [3]

The close relationship between serum level of LDL Cholesterol (LDL-C) and the chance of achieving SVR has been reported in patients under interferon based regimens [4].

Although higher SVR rates were achieved with DAAs treatment of $\mathrm{HCV}$, special attention must be paid to unexpected adverse events based on host metabolic changes [ $\mathbf{s}$.

Eradication of HCV with DAAs increases total cholesterol levels, due to the removal of the effect of HCV on cholesterol metabolism, because these regimens have no influence on the nutritional status of the host [6]

Although DAAs rarely fail to achieve viral eradication, a subset of patients experience treatment failure [7]. So, the changes in host lipid metabolism may be helpful for prediction of treatment response. 


\section{Patients and Methods}

This cohort prospective study was performed at the Viral Hepatitis Treatment Unit in Tanta University Teaching Hospital from Jan. 2017-Jan. 2018 and included 301 patients with chronic $\mathrm{HCV}$ who started treatment with interferon free regimen and completed the course and follow-up period (according to the protocol of national committee for treatment of viral hepatitis), then they are further divided into 2 groups; Group I which included 264 patients who have achieved SVR and Group II which included 37 patients who did not achieve SVR.

Exclusion criteria: Patients with hepatitis B infection or other forms of chronic liver disease and patients on lipid lowering medications.

The demographic data, gender, and age were collected at initiation of therapy. HCV antibody \& quantitative polymerase chain reaction for $\mathrm{HCV}$ RNA. Complete blood count, serum albumin, total and direct serum bilirubin, alanine transaminase, aspartate transaminase, international normalized ratio, serum creatinine, fasting blood glucose level, Hepatitis B surface antigen, Alpha fetoprotein and pregnancy test for females in the child-bearing period were included in the basic laboratory data.

Patients underwent further investigations in the form of $12 \mathrm{~h}$ fasting serum lipid profile including: Serum cholesterol, triglycerides, Low Density Lipoprotein (LDL) and High Density Lipoprotein (HDL) detected by commercial kits (bio systems). These tests were done before starting treatment (baseline) and at the end of treatment (EOT).

Statistical analysis: Statistical presentation and analysis of our study was conducted, by IBM SPSS statistics ${ }^{\circledR}$ Version 22. $p$-value $<0.05$ was considered statistically significant.

\section{Results}

A total of 301 chronic HCV-infected patients started interferon-free treatment with a combination of DAAs and RBV and were conducted on two groups according to achievement of SVR.

- Group I included 264 patients who have achieved SVR.

- Group II included 37 patients who did not achieve SVR.

As regards the demographic and baseline characteristics, all tested parameters showed nonsignificant differences between the two studied groups as shown in (Table 1).
Table (1): The demographic and baseline characteristics in the studied groups.

\begin{tabular}{|c|c|c|c|c|c|c|}
\hline \multirow[t]{2}{*}{ Variables } & \multicolumn{2}{|c|}{$\begin{array}{l}\text { Group I } \\
\text { SVR } \\
(n=264)\end{array}$} & \multicolumn{2}{|c|}{$\begin{array}{c}\text { Group II } \\
\text { Non-SVR } \\
(\mathrm{n}=37)\end{array}$} & \multirow[t]{2}{*}{$x^{2}$} & \multirow[t]{2}{*}{$p$} \\
\hline & $\mathrm{N}$ & $\%$ & $\mathrm{~N}$ & $\%$ & & \\
\hline $\begin{array}{l}\text { Age in years: } \\
- \text { Range }\end{array}$ & & & & & $\begin{array}{l}t= \\
0.834\end{array}$ & 0.405 \\
\hline $\begin{array}{l}\text { Sex: } \\
\text { - Male } \\
\text { - Female }\end{array}$ & $\begin{array}{l}107 \\
157\end{array}$ & $\begin{array}{l}89.2 \\
86.7\end{array}$ & $\begin{array}{l}13 \\
24\end{array}$ & $\begin{array}{l}10.8 \\
13.3\end{array}$ & 0.394 & 0.530 \\
\hline $\begin{array}{l}\text { Treatment status: } \\
\text { - Naïve } \\
\text { - Experienced } \\
(\text { PegINF + RBV) }\end{array}$ & $\begin{array}{l}251 \\
13\end{array}$ & $\begin{array}{l}87.2 \\
100.0\end{array}$ & $\begin{array}{l}37 \\
0\end{array}$ & $\begin{array}{l}12.8 \\
0.0\end{array}$ & FE & 0.381 \\
\hline $\begin{array}{l}\text { Treatment regimen: } \\
-\mathrm{SOF}+\mathrm{DAC}+\mathrm{RBV} \\
-\mathrm{SOF}+\mathrm{DAC}\end{array}$ & $\begin{array}{l}159 \\
105\end{array}$ & $\begin{array}{l}89.3 \\
85.4\end{array}$ & $\begin{array}{l}19 \\
18\end{array}$ & $\begin{array}{l}10.7 \\
14.6\end{array}$ & 1.058 & 0.304 \\
\hline
\end{tabular}

As regards baseline laboratory data between studied groups, all tested parameters showed nonsignificant differences between the two studied groups, except for the AFP. It was $11.30 \pm 21.16$ $(\mathrm{ng} / \mathrm{mL})$ in Group I, while it was $17.28 \pm 21.01$ $(\mathrm{ng} / \mathrm{mL})$ in Group II with significant difference between both groups $(p=0.001)$ as showen in (Table 2).

Table (2): Baseline laboratory data between studied groups.

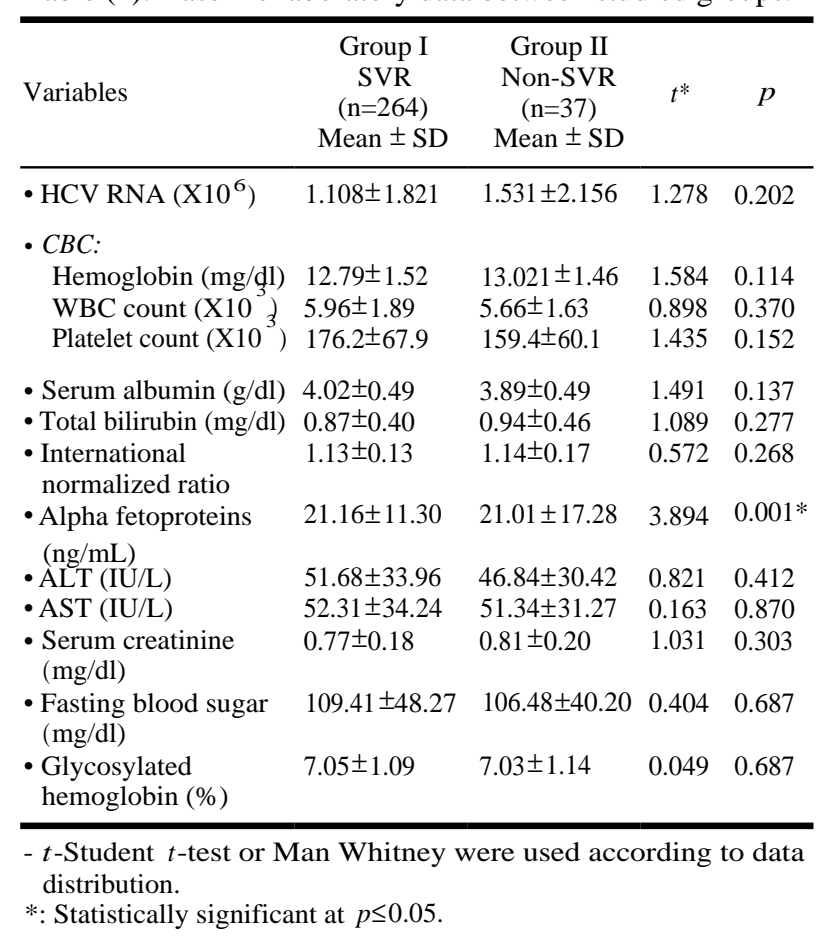

Comparison of changes in serum lipid levels between responders to antivirals Vs. relapsers: All tested parameters showed significant differences between both groups before treatment and at the end of treatment, as showen in (Table 3). 
Table (3): Changes in serum lipid profile levels between studied groups.

\begin{tabular}{|c|c|c|c|c|}
\hline & $\begin{array}{c}\text { Group I } \\
\text { SVR } \\
(\mathrm{n}=264)\end{array}$ & $\begin{array}{c}\text { Group II } \\
\text { Non-SVR } \\
(\mathrm{n}=37)\end{array}$ & $t$ & $p$ \\
\hline \multicolumn{5}{|l|}{ Serum cholesterol $(m g / d l)$ : } \\
\hline Before treatment (baseline) & $120.99 \pm 27.21$ & $87.14 \pm 22.41$ & 7.231 & $0.001 *$ \\
\hline End of treatment (EOT) & $200.94 \pm 28.31$ & $92.65 \pm 14.12$ & 37.316 & $0.001^{*}$ \\
\hline \multicolumn{5}{|l|}{ Serum triglycerides $(\mathrm{mg} / \mathrm{dl})$ : } \\
\hline Before treatment (baseline) & $75.21 \pm 27.83$ & $63.73 \pm 20.36$ & 2.418 & $0.016 *$ \\
\hline End of treatment (EOT) & $156.26 \pm 39.84$ & $68.70 \pm 18.89$ & 22.126 & $0.001 *$ \\
\hline \multicolumn{5}{|c|}{ Serum high density lipoproteins $(\mathrm{mg} / \mathrm{dl})$ : } \\
\hline Before treatment (baseline) & $53.64 \pm 16.40$ & $46.92 \pm 21.69$ & 2.238 & $0.026 *$ \\
\hline End of treatment (EOT) & $53.36 \pm 15.65$ & $44.97 \pm 19.93$ & 2.457 & $0.018 *$ \\
\hline \multicolumn{5}{|c|}{ Serum low density lipoproteins $(\mathrm{mg} / \mathrm{dl})$ : } \\
\hline Before treatment (baseline) & $52.16 \pm 25.93$ & $27.35 \pm 11.25$ & 10.157 & $0.001 *$ \\
\hline End of treatment (EOT) & $116.08 \pm 29.57$ & $33.78 \pm 15.22$ & 26.598 & $0.001 *$ \\
\hline
\end{tabular}

Changes in serum lipid levels in responders: Serum lipid parameters in GI showed highly significant increase in all tested parameters, except for serum HDL-C levels which showed nonsignificant changes between the baseline levels and at the end of treatment as showen in (Table 4).

Changes of serum lipid in non-responders: Serum lipid parameters in Group II showed nonsignificant difference between the baseline levels and at the end of treatment as showen in (Table 5).

Table (4): Serum lipid parameters at baseline and at the end of treatment in G1.

\begin{tabular}{|c|c|c|c|c|}
\hline & \multicolumn{2}{|c|}{ SVR } & \multirow{2}{*}{$t$} & \multirow{2}{*}{$p$} \\
\hline & Baseline & EOT & & \\
\hline $\begin{array}{l}\text { - Cholesterol: } \\
\text { Mean } \pm \text { SD } \\
\text { - } T G:\end{array}$ & $120.99 \pm 27.207$ & $200.938 \pm 28.306$ & -44.792 & $<0.001 *$ \\
\hline $\begin{array}{l}\text { Mean } \pm \text { SD } \\
\text { - } H D L:\end{array}$ & $75.206 \pm 27.833$ & $156.261 \pm 39.838$ & -33.354 & $<0.001 *$ \\
\hline $\begin{array}{l}\text { Mean } \pm \mathrm{SD} \\
\text { - } L D L:\end{array}$ & $53.644 \pm 16.396$ & $53.362 \pm 15.649$ & 0.730 & 0.466 \\
\hline Mean \pm SD & $52.159 \pm 25.929$ & $116.080 \pm 29.568$ & -36.173 & $<0.001^{*}$ \\
\hline
\end{tabular}

Table (5): Serum lipid parameters at baseline and at the end of treatment in G II.

\begin{tabular}{lcccc}
\hline & \multicolumn{2}{c}{ Non SVR } & \multicolumn{2}{c}{$\begin{array}{c}\text { Paired } \\
\text { Samples Test }\end{array}$} \\
\cline { 2 - 5 } & Baseline & EOT & $t$ & $p$ \\
\hline - Cholesterol: & & & & \\
$\quad \begin{array}{l}\text { Mean } \pm \text { SD } \\
\text { TG: }\end{array}$ & $87.135 \pm 22.412$ & $92.649 \pm 14.117$ & -1.956 & 0.058 \\
$\begin{array}{l}\text { Mean } \pm \text { SD } \\
\text { HDL: }\end{array}$ & $63.730 \pm 20.364$ & $68.703 \pm 18.894$ & -1.938 & 0.061 \\
$\begin{array}{l}\text { Mean } \pm \text { SD } \\
\text { - }\end{array}$ & $46 L:$ & & & \\
$\quad$ Mean \pm SD & $27.351 \pm 11.248$ & $33.784 \pm 15.221$ & -1.962 & 0.058 \\
\hline
\end{tabular}

\section{Discussion}

Egypt has a very high burden of infection and disease: Egypt ranks the 5 th amongst all countries for the burden of disease from viral hepatitis $\mathrm{C}$ [8] The availability of DAAs with excellent efficacy and good tolerability profiles offer a unique opportunity to achieve HCV elimination worldwide. However, viral clearance with DAAs has led to a global worsening of lipid profile.

In this study, we investigated the changes in serum lipid profile with INF-free treatment regimens in Egyptian patients with chronic HCV infection, its association with the treatment outcome.

Regarding patients' gender, sixty percent of patients were females and $40 \%$ were males. The female predominance in our study differs with ElSerag, [9] who reported male predominance, which was attributed to reluctance of the Egyptian rural female population to participate in national health programs. However, the female predominance in our study might be due an increased awareness about viral hepatitis through a nationwide screening campaigns that encourage female population to participate and receive treatment.

As regard previous treatment status, $4 \%$ of treated patients were treatment-experienced (PegINF + RBV); all of them (100\%) have achieved SVR. This is concordant with Wyles et al., [10] who reported SVR $98 \%$ of patients previously treated with an interferon-based regimen on SOF plus DAC + RBV, but differs with Nelson et al., [11] who reported SVR $86 \%$ in patients using SOF plus DAC + RBV regimen. The difference in findings across these studies might be due to different number of treatment-experienced patients included in our study and theirs and different genotypes. 
In the current study, 264 patients $(88 \%)$ have achieved SVR. Our results are in agreement with Nelson et al., [11] who stated that a 12-week regimen of SOF plus DAC + RBV was associated with an overall SVR rate of $89 \%$ [11]. However, Fontaine et al., [12] reported SVR 100\% in treatment of genotype $4 \mathrm{HCV}$ using the same regimen. The difference might be attributed to higher number of patients included in our study (301 vs. 47).

In this study, the mean HCV RNA level in Group I was $1.108+1.821\left(\mathrm{X} 10^{6}\right) \mathrm{IU} / \mathrm{mL}$, while in Group II was $1.531+2.156\left(X 10^{6}\right) \mathrm{IU} / \mathrm{mL}$ with no significant difference between both groups. This is in accordance with Nelson et al., [11] who reported that there is no link between baseline HCV viral load and SVR, but differs with Kowdley et al., [13] who found that a very high baseline viral level ( $>6$ million IU/ml) was shown to be associated with reduced likelihood of SVR. The difference might be due to different genotype, treatment regimen and duration of therapy (12w vs. $8 w$ ) between our study and theirs.

Regarding serum alpha fetoproteins in our study, it's level ranged from 0.3-237 with mean 21.16 $11.30(\mathrm{ng} / \mathrm{mL})$ in Group I, while it ranged from 1104 with mean $21.01 \pm 17.28(\mathrm{ng} / \mathrm{mL})$ in Group II with a significant difference between both groups. This was similarly reported by Akuta et al., [14], who found that high level of AFP is a pretreatment predictor of poor virological response to therapy.

We proposed a real-life study with analysis of the changes in lipid profile. In our study, there was a statistically significant difference between responder and non-responder group as regard pretreatment cholesterol, LDL, HDL and triglycerides levels. We found that these baseline lipid parameters were higher in Group I compared to Group II as regard LDL-C level, total cholesterol level, and serum triglycerides. This is in agreement with the findings of Ogawa et al., [15] who found that the higher the baseline lipid levels, the greater the chance of curing hepatitis $\mathrm{C}$.

We demonstrated in our study that viral clearance due to DAAs led to significant rise from the baseline levels as regard total cholesterol, triglycerides and LDL-C. We also observed that Total Cholesterol (TC), Triglycerides (TG) and LDL-C significantly increased gradually over the course of the therapy, which continued after treatment discontinuation. No meaningful increase in HDL$\mathrm{C}$ level in responders was found. These findings are consistent with Hashimoto et al., [16] and Mauss et al., [17] who reported that the increase in total cholesterol and LDL but not in HDL levels following SVR with DAAs therapy thought to reflect the role of the intrahepatic cholesterol biosynthetic pathway in HCV replication cycle. Also, Hashimoto et al., [16] suggested that DAAs in addition to have an anti-HCV effect, they themselves might have pharmacological effects on serum lipid levels, especially on LDL-C [16].

Hashimoto et al., 2016 suggested that the rapid suppression of $\mathrm{HCV}$ core protein by DAA might result in a decrease of lipid droplet production in $\mathrm{HCV}$-infected liver cells, leading to a massive rebound of circulating LDL [16]

In our study, we noticed that in patients who failed to achieve treatment response, there were non-significant changes in the all tested lipid profile at baseline, and after discontinuation of treatment. Our results were in agreement with Meissner et al., [18] who stated that mean serum LDL was lower in patients who relapsed versus achieved SVR at baseline and post-treatment.

This study has some limitations. Other parameters that might alter the results, such as a change of body weight, dietary modifications, and the amount of exercise were not available.

\section{Conclusion:}

In this study, we could conclude that eradication of HCV with DAAs was associated with increased level of LDL, TC and TG levels.

\section{Conflict of interest:}

No conflicts of interest declared.

\section{Acknowledgments:}

This research was carried out without funding.

\section{References}

1- MORGAN R., BAACK B., SMITH B., YARTEL A., PITASI M. and FALCK-YTTER Y.: Eradication of hepatitis $\mathrm{C}$ virus infection and the development of hepatocellular carcinoma: A meta-analysis of observational studies. Ann. Intern. Med., 158: 329-37, 2013.

2- ASSELAH T, BOYER N, SAADOUN D, MARTINOTPEIGNOUX M. and MARCELLIN P.: Direct-acting antivirals for the treatment of hepatitis $\mathrm{C}$ virus infection: Optimizing current IFN-free treatment and future perspectives. Liver Int., 36 (Suppl 1): 47-57, 2016.

3- ZHANG F., SODROSKI C., CHA H., LI Q. and LIANG T.: Infection of Hepatocytes with HCV Increases Cell Surface Levels of Heparan Sulfate Proteoglycans, Uptake of Cholesterol and Lipoprotein, and Virus Entry by Upregulating SMAD6 and SMAD7. Gastroenterol., 152: 257-70, 2017.

4- ROJAS Á., DEL CAMPO J., MARAVER M., APARCERO R., GARCÍA-VALDECASAS M., DIAGO M., et al.: 
Hepatitis $\mathrm{C}$ virus infection alters lipid metabolism depending on IL28B polymorphism and viral genotype and modulates gene expression in vivo and in vitro. J. Viral Hepat., 21: 19-24, 2014.

5- GITTO S., CICERO A., LOGGI E., GIOVANNINI M., CONTI F., GRANDIN E., et al.: Worsening of serum lipid profile after direct acting antiviral treatment. J. Hepatol., 66: S740, 2017.

6- ENDO D., SATOH K., SHIMADA N., HOKARI A. and AIZAWA Y.: Impact of interferon-free antivirus therapy on lipid profiles in patients with chronic hepatitis C genotype 1b. World J. Gastroenterol., 23: 2355-64, 2017.

7- TERRAULT N.: Difficult-to-cure populations with chronic hepatitis C: Vanishing in the direct-acting antiviral era? Hepatol., 62: 4-7, 2015.

8- STANAWAY J., FLAXMAN A., NAGHAVI M., FITZMAURICE C., VOS T., ABUBAKAR I., et al.: The global burden of viral hepatitis from 1990 to 2013: findings from the Global Burden of Disease Study 2013. Lancet, 388 (10049): 1081-8, 2016.

9- EL SERAG H.: Epidemiology of Viral Hepatitis and Hepatocellular Carcinoma. Gastroenterol., 142: 1264-73, 2012.

10- WYLES D., RUANE P., SULKOWSKI M., DIETERICH D., LUETKEMEYER A., MORGAN T., et al.: Daclatasvir plus sofosbuvir for $\mathrm{HCV}$ in patients co-infected with HIV1. N. Engl. J. Med., 373: 714-25, 2015.

11- NELSON D., COOPER J., LALEZARI J., LAWITZ E., POCKROS P., GITLIN N., et al.: All-oral 12-week treatment with daclatasvir plus sofosbuvir in patients with hepatitis C virus genotype 3 infection: ALLY-3 phase III study. Hepatol., 61: 1127-35, 2015.
12- FONTAINE H., HEZODE C., ZOULIM F., SAMUEL D., BOURLIERE M., HAOUR G., et al.: Efficacy of the oral sofosbuvir based combinations in HCV genotype 4monoinfected patients from the French observational cohort ANRS CO22 Hepather. Abstract LP28 presented at: $50^{\text {th }}$ Annual Meeting of European Association for the Study of the Liver, April 22-26, Vienna, Austria, 2015.

13- KOWDLEY K., GORDON S., REDDY K., ROSSARO L., BERNSTEIN D., LAWITZ E., et al.: Ledipasvir and sofosbuvir for 8 or 12 weeks for chronic HCV without cirrhosis. N. Engl. J. Med., 370: 1879-88, 2014.

14- AKUTA N., SUZUKI F., SEKO Y., KAWAMURA Y., SEZAKI H., SUZUKI Y., et al.: "Determinants of response to triple therapy of telaprevir, peginterferon, and ribavirin in previous non-responders infected with HCV genotype 1,” J. Med. Virol., 84: 1097-105, 2012.

15- OGAWA E., FURUSYO N., KAJIWARA E., NOMURA H., DOHMEN K., TAKAHASHI K., et al.: Influence of low-density lipoprotein cholesterol on virological response to telaprevir-based triple therapy for chronic HCV genotype 1b infection. Antiviral Res., 104: 102-9, 2014.

16- HASHIMOTO S., YATSUHASHI H., ABIRU S., YAMASAKI K., KOMORI A., NAGAOKA S., et al.: Rapid Increase in Serum Low- Density Lipoprotein Cholesterol Concentration during Hepatitis C Interferon-Free Treatment. PLoS One, 11: e0163644, 2016.

17- MAUSS S., BERGER F., WEHMEYER M., INGILIZ P., HUEPPE D., LUTZ T., et al.: Effect of antiviral therapy for HCV on lipid levels. Antivir. Ther., 21: 81-8, 2016.

18- MEISSNER E., LEE Y., OSINUSI A., SIMS Z., QIN J., STURDEVANT D., et al.: Effect of sofosbuvir and ribavirin treatment on peripheral and hepatic lipid metabolism in chronic hepatitis $\mathrm{C}$ virus, genotype 1-infected patients. Hepatol., 61: 790-801, 2015. 


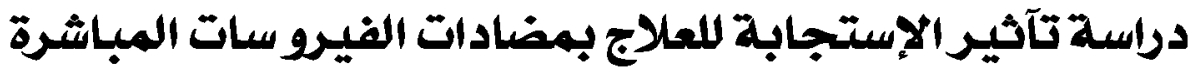 على مستوى الدهون بالدم فى المرضى المصريين

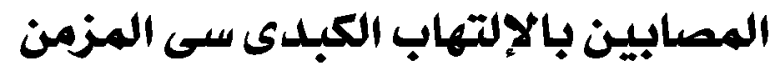

تعتبر مصر من بين البلدان ذات آعلى معدلات إنتشار العدوى بالفيروس الكبدى (سى) في العالم، حيث يعتبر النمط البينى ع هو النمط

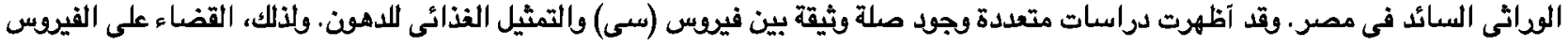

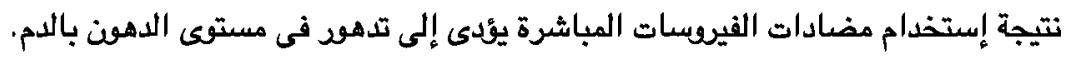

الهدف من الدراسة: دراسة التغيرات في مستوى الدهن في الدم مع نظم العلاج الخالية من الإنترفيرون في المرضى المصريين المصابين بالإلتهاب الكبدى (سى) المزمن وإرتباطه بنتائج العلاج.

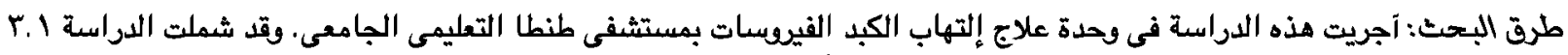

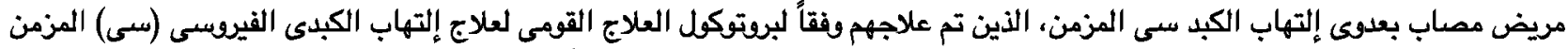

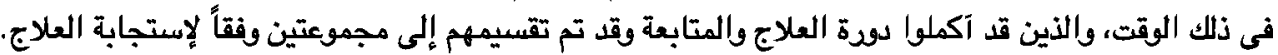

النتائج: فيما يتعلق بالخصائص الديموغرافية الآساسية للمرضى وتحليل ما قبل العلاج، آظهرت النتائج عدم وجود فرق إحصائى بين

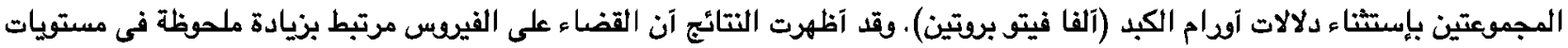

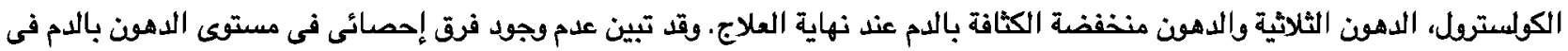
المرضى الذين لم يحققى إستجابة اللعلاج.

الإستتاج: إن نظم العلاج بإستخدام سوفوسبوفير بالإضافة إلى دكلاتزفير مع آو بلون ريبافيرن لمدة با إسبوع، كان لها نتائج إيجابية

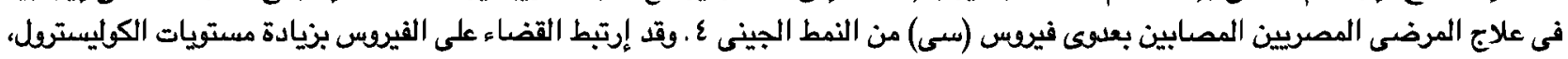

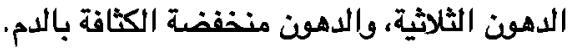

